\title{
Magnetic Properties, Corrosion Resistance and Crystallization Behavior of Nd-Fe-B Alloys
}

\author{
Y. Gu ${ }^{1, *}$, S.H.Hua ${ }^{2}$, M.X.Pan ${ }^{2}$, Z.H. Huang ${ }^{2}$ \\ ${ }^{1}$ Qianjiang College, Hangzhou Normal University, Hangzhou, 310036, P. R. China \\ ${ }^{2}$ Zhejiang Fangyuan Test Group Co., LTD, Hangzhou, 310018, China \\ *E-mail: guyonghz@126.com (Yong Gu)
}

doi: $10.20964 / 2020.06 .52$

Received: 25 February 2020 / Accepted: 30 March 2020 / Published: 10 May 2020

\begin{abstract}
The microstructure and magnetic properties of the over-quenching (OQ), over-quenching followed by annealing and optimum direct quenching (DQ) for the $\mathrm{Nd}_{11} \mathrm{Fe}_{83} \mathrm{~B}_{6}$ alloys are studied. It is shown that the $\mathrm{OQ}+$ annealed $\alpha-\mathrm{Fe} / \mathrm{Nd}_{2} \mathrm{Fe}_{14} \mathrm{~B}$ alloy possesses a smaller and homogeneity nanocrystal microstructure, compared to the optimum DQ $\alpha-\mathrm{Fe} / \mathrm{Nd}_{2} \mathrm{Fe}_{14} \mathrm{~B}$ alloy. Meanwhile, the proper OQ + annealed is optimal to enhance the corrosion resistance and the magnetic properties $\left(M_{\mathrm{r}}=87.44 \mathrm{emu} / \mathrm{g}\right.$, $\left.H_{\mathrm{cj}}=329 \mathrm{kA} / \mathrm{m},(B H)_{\max }=64.42 \mathrm{~kJ} / \mathrm{m}^{3}\right)$ of the $\alpha-\mathrm{Fe} / \mathrm{Nd}_{2} \mathrm{Fe}_{14} \mathrm{~B}$ nanocomposite alloys. The apparent activation energies $E_{c}(x)$ of crystallization for $\mathrm{Nd}_{2} \mathrm{Fe}_{14} \mathrm{~B}$ and $\alpha$-Fe phase show that nucleation is difficult and growth is easy in the process of amorphous crystallization for the over-quenching (OQ) alloy.
\end{abstract}

Keywords: Magnetic property; Corrosion; Crystallization behavior

\section{$\underline{\text { FULL TEXT }}$}

(C) 2020 The Authors. Published by ESG (www.electrochemsci.org). This article is an open access article distributed under the terms and conditions of the Creative Commons Attribution license (http://creativecommons.org/licenses/by/4.0/). 